\title{
Pengaruh Konsentrasi Asap Cair Terhadap Mutu, Total Bakteri, dan Waktu Simpan Ikan Cakalang (Katsuwonus pelamis) Asap
}

\section{[Effect of Liquid Smoke Concentration on Quality, Total Bacteria, and Shelf Life of Smoked Skipjack Fish (Katsuwonus pelamis)]}

\author{
Angria Deswika Malambu*, Syaiful Bahri, Hardi Ys., Prismawiryanti, Abd. Rahman Razak
}

Jurusan Kimia Fakultas MIPA Universitas Tadulako, Indonesia

\begin{abstract}
Liquid smoke contains acid, carbonyl, and phenolic compounds, so it is very appropriate to be used as a preservative. Traditional smoking can be replaced with liquid smoke because it is safer and more practical. The study of the use of coconut shell liquid smoke has been used in skipjack fish to determine the effect of liquid smoke concentration and storage time on dissolved protein content and total bacteria in smoked fish. The quality of smoked fish was determined by two treatments, namely the variation in the concentration of liquid smoke $(2,3,4$, and $5 \%)$ and storage time $(2,4,6,8$, and 10 days). The results showed that the best concentration of liquid smoke to produce smoked skipjack fish is $3 \%$ with water content of $62.41 \%$ and dissolved protein content of $17.58 \%$. The maximum storage time of smoked skipjack tuna is 6 days with a total plate count (TPC) value or total bacteria 1.8 $\times 10^{5}$.
\end{abstract}

Keywords: Liquid smoke, smoked skipjack fish, total plate count, dissolved protein

Abstrak. Asap cair memiliki kandungan senyawa asam, karbonil, dan fenolat sehingga sangat tepat digunakan sebagai bahan pengawet. Pengasapan tradisional dapat digantikan dengan asap cair karena lebih aman dan praktis. Kajian penggunaa asap cair tempurung kelapa telah digunakan pada ikan cakalang untuk mengetahui pengaruh konsentrasi asapa cair dan waktu simpan terhadap kadar protein terlarut dan total bakteri pada ikan asap. Kualitas ikan asap dilihat dengan dua perlakuan, yaitu pada variasi konsentrasi asap cair 2; 3; 4 dan $5 \%$, dan lama penyimpanan yaitu 2; 4; 6; 8 dan 10 hari. Hasil penelitian menunjukan bahwa konsentrasi asap cair terbaik untuk membuat ikan cakalang asap adalah $3 \%$ dengan nilai kadar air $62,41 \%$ dan kadar protein terlarut $17,58 \%$. Waktu penyimpanan maksimal dari ikan cakalang asap adalah 6 hari dengan nilai total plate count (TPC) atau total bakteri $1,8 \times 10^{5}$.

Kata kunci: Asap cair, ikan cakalang asap, total plate count, protein terlarut.

Diterima: 7 November 2019, Disetujui: 12 April 2021

Sitasi: Malambu, A. D., Bahri, S., Ys, H., Prismawiryanti., \& Razak, A.R. (2021). Pengaruh Konsentrasi Asap Cair Terhadap Mutu, Total Bakteri, dan Waktu Simpan Ikan Cakalang (Katsuwonus pelamis) Asap. KOVALEN: Jurnal Riset Kimia, 7(1): 59-64.

\section{LATAR BELAKANG}

Ikan merupakan salah satu ikan yang tersebar diseluruh wilayah laut Indonesia. Pengolahan modern dari ikan cakalang ini dapat dijumpai dalam bentuk abon yang telah dikemas, bakso ikan, ikan kaleng dan bentuk

\footnotetext{
* Corresponding author

E-mail: angria11_22@gmail.com
}

pengolahan tradisional dari ikan cakalang ini dapat ditemukan seperti pada ikan asap yang biasanya dijual dipasaran (Angela et al., 2015).

Ikan cakalang asap selama ini hanya dalam bentuk hasil olahan secara tradisional, sehingga diperlukan teknik yang lebih modern. Pengasapan merupakan kombinasi proses penggaraman, pemanasan, dan pelekatan komponen kimiawi asap. Pengolahan ini 
bertujuan untuk mengawetkan dan meningkatkan daya simpan ikan serta memberi warna dan aroma khas dari ikan asap. Salah satu permasalahan dari proses pembuatan ikan asap ialah kualitas ikan asap yang dapat berubah-ubah dikarenkan belum adanya proses yang baku. Kondisi yang berubah-ubah menyebabkan perbedaan dari kualitas ikan asap yang dihasilkan dan berpengaruh terhadap tingkat kesukaan dari konsumen (Swastawati et al., 2017).

Pengasapan juga dapat diartikan sebagai proses penetrasi senyawa volatil dari dalam daging ikan (Palm et al., 2011), sehingga menghasilkan produk dengan cita rasa dan aroma yang khas serta memiliki umur simpan yang lebih lama. Beberapa senyawa kimia dari asap kayu, antara lain senyawa fenol, asam organik, alkohol, aldehid, keton, ester, eter, hidrokarbon, dan nitro oksida. Senyawasenyawa tersebut akan menempel pada permukaan daging ikan dan terserap ke dalam daging ikan (Isamu et al., 2013).

Beberapa tahun terakhir, asap cair banyak diproduksi sebagai pengganti asap konvensional pada proses pengasapan ikan. Fungsi dari asap cair sebagai antibakteri dimana asap cair mengandung asam, derivat fenol, dan karbonil. Asap cair dapat berfungsi sebagai pengawet karena memiliki nilai $\mathrm{pH}$ asam (Kurniasih et al., 2016), sehingga mampu menghambat pertumbuhan bakteri-bakteri patogen, seperti E. Coli, Vibrio cholerae, Staphylococcus aureus, dan Sallmonella sp. (Hadinoto et al., 2016).

Mikroorganisme dapat ditemukan dimana saja, seperti pada tanah, debu, udara, air jaringan tubuh bahkan pada makanan yang biasa nya dikonsumsi. Mikroorganisme ada yang bermanfaat untuk kelangsungan hidup tetapi tidak jarang juga mikroorganisme yang merugikan mahluk hidup, contohnya pada manusia mikroorganisme dapat menimbulkan berbagai macam penyakit bahkan kerusakan efek kontaminasi mikroba (Ratna, 1990). Mikroorganisme pada bahan makanan juga tidak dapat dihindari, mikroorganisme dapat tumbuh dan berkembang pada tergantung dari kualitas dan kebersihan makanan tersebut. Penelitan yang dilakukan mengarah pada kajian terbaru mengenai kadar protein terlarut dan total bakteri pada ikan cakalang setelah direndam dalam asap cair.

\section{METODE PENELITIAN}

\section{Bahan dan Peralatan}

Bahan yang digunakan meliputi ikan cakalang segar dari pasar tradisional di Kota Palu, asap cair tempurung kelapa , $\mathrm{NaCl}$ p.a, akuades, $\mathrm{NaOH}$, media NA. Alat yang digunakan terdiri atas autoclave, neraca analitik (Adventurer ohaus), blender, cawan petri, oven (Memmert), termometer, spektrovotometer UVvisible (PerkinElmer L850), batang penyebar gelas sreril, stopwatch, mortar, blender, sentrifugasi, dan colony counter.

\section{Prosedur Penelitian}

\section{Pembuatan ikan cakalang asap}

Sampel Ikan cakalang segar dibersihkan kemudian dicuci dengan larutan garam, selanjutnya direndam dalam larutan asap cair tempurung kelapa selama 30 menit, masing-masing pada konsentrasi $2 \%, 3 \%$, $4 \%$, dan 5\%. Hasil rendaman ditiriskan selama \pm 1 jam, selanjutnya dioven pada suhu $60-70^{\circ} \mathrm{C}$ selama 2 jam. Ikan cakalang asap selanjutnya didinginkan pada suhu ruang selama \pm 1 jam agar tidak keluar uap air selama pengemasan. Ikan cakalang asap disimpan pada suhu ruang selama 10 hari 
dan dianalisis pada hari ke-2, 4, 6, 8 dan 10 hari (Swastawati et al., 2017).

\section{Uji protein}

Uji kandungan protein dilakukan dengan metode spektrofotometri UV-VIS atau metode Warburg-Christian. Sampel ikan cakalang asap sebanyak $0,25 \mathrm{gr}$ dihaluskan, ditambahkan dengan $25 \mathrm{ml} \mathrm{NaOH} 10 \%$, sheaker selama 30 menit. Larutan kemudian disaring. Hasil ekstraksi diukur kadar proteinnya menggunakan spketrofotometer UV-visible pada panjang gelombang antara 280 nm dan 260 nm (Dyer et al., 2000).

$\%$ Protein Terlarut $=\frac{\mathrm{Fk} \times \text { Volume larutan } \times \mathrm{Fp}}{\text { Berat sampel }} \times 100$

Keterangan:

$\mathrm{Fk}=$ Faktor koreksi

$\mathrm{Fp}=$ Faktor pengenceran

\section{Uji mikroba}

Sampel $10 \mathrm{~g}$ ditambahkan dengan 90 $\mathrm{ml}$ aquades kemudian diblender hingga homogen (sampel suspensi pengenceran 101). Larutan suspense sebanyak $1 \mathrm{~mL}$ diencerkan berturut-turut sampai pengenceran $10^{-7}$. Pada setiap pengenceran diambil $1 \mathrm{~mL}$ larutan lalu dituangkan dalam media NA dan diinkubasi selama 24 jam pada suhu $37^{\circ} \mathrm{C}$. Kemudian dihitung jumlah koloni pada masing-masing petri. Pada setiap pengeceran dilakukan 2 kali pengulangan (duplo) (ljong \& Suwetja, 2003). Jumlah koloni pada cawan petri antara 30-300 koloni dan dalam keadaan koloni bebas, dengan persmaan berikut:

$$
\text { TPC }=\mathbf{Z} \text { koloni } \times \frac{1}{\text { Pengenceran }} \times \frac{1}{\text { Jumlah yang disebar }}
$$

Keterangan :

TPC = Total Plate Count

$\mathrm{Z}$ Koloni $=$ Jumlah Koloni

\section{HASIL DAN PEMBAHASAN}

\section{Ikan Cakang Hasil Perendaman}

Ikan cakalang (Katsuwonus pelamis) dicuci dalam larutan $\mathrm{NaCl} 5 \%$ bertujuan untuk membunuh serta menghambat proses tumbuhnya bakteri pada ikan karena $\mathrm{NaCl}$ dapat berfungsi sebagai antibakteri. Perendaman ikan cakalang dalam asap cair tempurung kelapa akan mengakibatkan senayawa fenol dari asap cair akan masuk ke dalam daging ikan cakalang, sehingga menghasilkan aroma khas asap. Selain itu, efek perendaman juga akan mempengaruhi bentuk fisik dari ikan (Gambar 1).

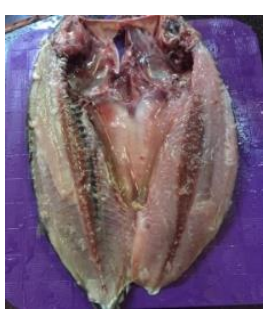

(a)

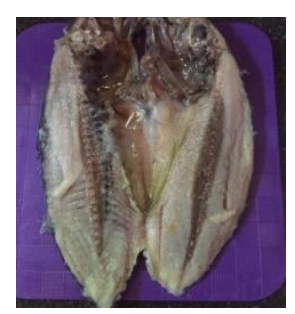

(b)
Gambar 1. Perbedaan fisik ikan cakalang sebelum (a) dan setelah direndam (b) asap cair

Pada Gambar 1 dapat terlihat bahwa ikan yang tidak direndam dengan asap cair terlihat berwarna coklat dan segar (a), sedangkan ikan yang telah direndam dengan asap cair (b) selama 30 menit daging ikan menjadi keputih-putihan dan sedikit lebih matang. Menurut Isamu et al. (2013), senyawa volatil yang terdapat pada asap cair seperti senyawa karbonil dan fenol kemungkinan akan berinteraksi dengan senyawa protein pada ikan sehingga akan menyebabkan terjadinya perubahan warna, rasa, serta aroma pada ikan asap.

\section{Kadar Air Ikan Cakalang Asap}

Hasil penelitian menunjukkan bahwa terdapat perbedaan siginifikan antara kadar air 
pada ikan cakalang yang telah direndam dengan asap cair dibandingkan dengan kadar air pada ikan cakalang yang tidak direndam dengan asap cair (Gambar 2).

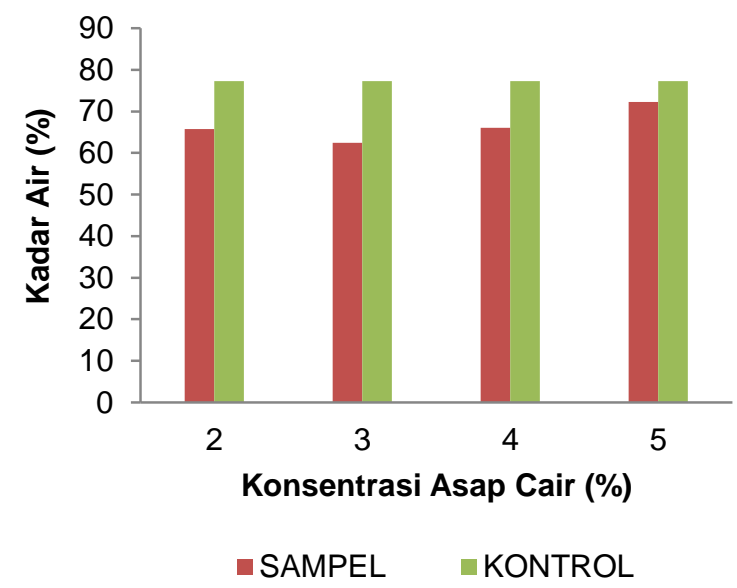

Gambar 2. Hubungan konsentrasi asam cair terhadap kadar air ikan cakalang asap

Hasil pengukuran kadar air ikan cakalang pada konsentrasi $2 \%$ yaitu $65,75 \%$, pada konsentrasi $3 \%$ yaitu $62,41 \%$, konsentrasi 4\% diperoleh kadar air sebesar $66,05 \%$ dan pada konsentrasi $5 \%$ sebesar $77,25 \%$ (Gambar 2). Penurunan nilai kadar air dari penggunaan asap cair $2 \%$ ke $3 \%$ terjadi karena asap cair semakin banyak meresap ke dalam daging ikan cakalang secara osmosis, sehingga menyebabkan kandungan air tubuh ikan akan terdesak keluar (Herwati et al., 2017). Akan tetapi, pada penggunaan asap cair 4\% dan $5 \%$, kadar air kembali bertambah. Asap cair memliki kandungan senyawa fenol, sehingga saat konsentrasi asap cair terlalu tinggi, maka kadar fenol yang terserap ke dalam daging ikan juga semakin tinggi, sehingga menghambat air keluar dari daging ikan (Gómez- Guillén et al., 2000). Kadar air ikan asap yang dipersyaratkan dalam SNI adalah pada kisaran $65 \%$, dengan demikian kadar ikan cakalang asap yang diperoleh masih sesuai baku mutu pada penggunaan asap cair
3\%. Hadinoto et al. (2016) juga melakukan perendaman ikan cakalang dengan asap cair tempurung kelapa tanpa variasi konsentrasi asap cair, mendapatkan kadar air dari ikan cakalng asap hingga 59\%.

\section{Kadar Protein Terlarut Ikan Cakalang Asap \\ Protein \\ terlarut \\ ditentukan}

konsentrasinya dengan metode spektrofometrl Uv-Vis.

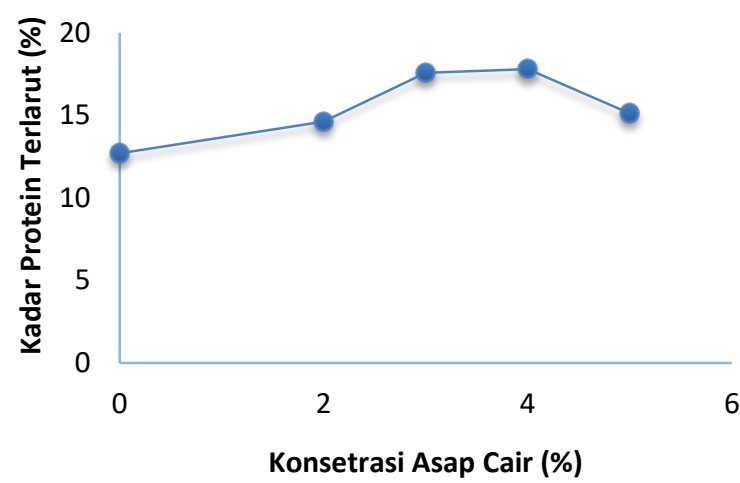

Gambar 3. Hubungan konsentrasi asap cair terhadap kadar protein terlarut ikan cakalang asap

Hasil penenlitian menunjukkan bahwa pada konsentrasi asap cair $2 \%, 3 \%$. $4 \%$ dan $5 \%$ berturut turut memiliki kadar protein terlarut 14,63\%, 17,58\%, 17,80\% dan 15,12\% (Gambar 3). Kadar protein tertinggi diperoleh pada konsentrasi asap cair $4 \%$ dengan nilai $17,80 \%$. Rasydita et al. (2015) melaporkan bahwa penggunaan asap cair tempurung kelapa dengan konsentrasi $2 \%$ pada ikan bandeng, kandungan protein terlarut didapatkan hingga $20,40 \%$. Penggunaan konsentrasi asap cair 3\% adalah perlakuan terbaik, karena memiliki nilai kadar air yang memenuhi syarat SNI dan memiliki kadar protein terlarut yang tinggi.

\section{Pengaruh Waktu Simpan terhadap TPC (Total Plate Count)}

Konsentrasi asap cair yang digunakan pada penentuan waktu simpan ialah $3 \%$, karena kadar air $<65 \%$ dan kadar protein 
terlarut hingga $17,58 \%$. Nilai TPC dari ikan cakalang asap yang diperoleh selama masa penyimpanan data menunjukan pertumbuhan jumlah bakteri ikan cakalang pada penyimpanan 0-6 hari relatif stabil, sehingga tidak terjadi peningkatan yang signifikan terhadap jumlah nilai TPC (Tabel 1). Hal ini disebabkan oleh adanya senyawa fenol pada asap cair yang berfungsi sebagai antibakteri, selain itu, diasumsikan ketersediaan oksigen yang terbatas juga dapat menghambat petumbuhan mikroba. Pada penyimpanan 8 hingga 10 hari terjadi peningkatan nilai koloni bakteri yang signifikan yang disebabkan oleh adaptasi dari bakteri dan kapang yang mulai bertumbuh dan berkembangbiak.

Tabel 1. Nilai TPC ikan cakalang asap pada berbagai waktu simpan

\begin{tabular}{cc}
\hline $\begin{array}{c}\text { Waktu Simpan } \\
\text { (Hari) }\end{array}$ & Nilai TPC \\
\hline 0 & $1.1 \times 10^{4}$ \\
2 & $8.1 \times 10^{4}$ \\
4 & $8.6 \times 10^{4}$ \\
6 & $1.8 \times 10^{5}$ \\
8 & $1.9 \times 10^{9}$ \\
10 & $1.9 \times 10^{9}$ \\
\hline
\end{tabular}

Pada penelitian ini, Ikan cakalang asap disimpan pada suhu ruang, sehingga penyimpanan maksimal 10 hari, tetapi jika ikan disimpan pada lemari pendingin dengan suhu rendah penyimpanan dapat mencapai 3-4 minggu. Hal ini dipertegas oleh llyas (1983) dimana pertumbuhan bakteri pada ikan sangat dipengaruhi oleh suhu, semakin rendahnya suhu ikan semakin lambat pertumbuhan bakteri.

Hasil penelitian ini menunjukkan bahwa waktu penyimpanan maksimal, yaitu hingga pada hari ke- 6 dengan total bakteri $1,8 \times 10^{5}$. SNI 01-2729-2006 mempersyaratkan nilai maksimum mikroba pada ikan asap, yaitu $50 \times 10^{5}$. Sutanaya et al. (2018) melaporkan bahwa umur simpan fillet ikan tuna yang telah direndam dengan asap cair tempurung kelapa mampu bertahan hingga 54 jam pada penyimpanan suhu ruang, sedangkan Febriani (2006) melaporkan perendaman belut dalam $30 \%$ asap cair tempurung kelapa selama 15 menit pada suhu ruang, memiliki umur simpan hingga 9 hari.

\section{KESIMPULAN}

Penggunaan konsentrasi asap cair tempurung kelapa 3\% merupakan konsentrasi terbaik dengan nilai kadar air $62,41 \%$ dan kadar protein terlarut hingga $17,58 \%$. Ikan cakalang asap dapat disimpan hingga 6 hari pada suhu ruang dengan nilai TPC adalah $1,8 \times 10^{5}$ atau telah memenuhi standar SNI.

\section{DAFTAR PUSTAKA}

Angela, G. C., Mentang, F., \& Sanger, G. (2015). Kajian Mutu Ikan Cakalang (Katsuwonus pelamis L.) Asap Dari Tempat Pengasapan Desa Girian Atas Yang Dikemas Vakum Dan Non Vakum Selama Penyimpanan Dingin. Media Teknologi Hasil Perikanan, 3(2), Article 2. https://doi.org/10.35800/mthp.3.2.2015. 9219

Dyer, D. L., Shinder, A., \& Shinder, F. (2000). Alcohol-free instant hand sanitizer reduces elementary school illness absenteeism. Family Medicine, 32 (9), 633-638.

Febriani, R. A. (2006). Pengaruh Konsentrasi Larutan Asap Cair Terhadap Mutu Belut (Monopterus albus) Asap yang Disimpan pada Suhu Kamar [Skripsi]. Institut Pertanian Bogor.

Gómez-Guillén, M. C., Montero, P., Hurtado, O., \& Borderías, A. J. (2000). Biological Characteristics Affect the Quality of Farmed Atlantic Salmon and Smoked 
Muscle. Journal of Food Science, 65(1), 53-60. https://doi.org/10.1111/j.13652621.2000.tb15955.x

Hadinoto, S., Kolanus, J. P., \& Manduapessy, K. R. (2016). Karakteristik Mutu Ikan Cakalang (Katsuwonus pelamis) Asap Menggunakan Asap Cair Dari Tempurung Kelapa. Majalah BIAM, 12(1), 20-26. https://doi.org/10.29360/mb.v12i1.2324

Herwati, E., Prarudianto, A., \& Saloko, S. (2017). The Effect of Liquid Smoke Powder of Coconut (Cocos nucifera Linn) Concentration and Storage Time in Smoked Milkfish Presto Quality. Jurnal IImiah Rekayasa Pertanian dan Biosistem, 5(1), 348-359. https://doi.org/10.29303/jrpb.v5i1.47

ljong, F. G., \& Suwetja, I. K. (2003). Kandungan merkuri pada Ikan yang ditangkap di Teluk buyat [Laporan Hasil Penelitian]. Universitas Sam Ratulangi, Manado.

llyas, S. (1983). Terknologi Refrigasi Hasil Perikanan. Jilid 1. Teknik Pedinginan Ikan. C. V. Paripurna, Jakarta.

Isamu, K. T., Purnomo, H., \& Yuwono, S. S. (2013). Parameter Kualitas Ikan Cakalang (Katsuwonus pelamis) Asap Menggunakan Bahan Pengasap yang Berbeda. Aqua Hayati, 9(1). https://www.neliti.com/id/publications/21 7725/

Kurniasih, R. A., Darmadji, P., \& Pranoto, Y. (2016). Pemanfaatan Asap Cair Terenkapsulasi Maltodesktrin-Kitosan Sebagai Pengawet Ikan Cakalang (Katsuwonus pelamis). Jurnal Teknologi Hasil Pertanian, 9(1), Article 1. https://doi.org/10.20961/jthp.v9i2.12846

Palm, L., Carboo, D., yeboah, O. P., Quasie, W., Gorleku, M., \& Darko, A. (2011). Characterization of Polycyclic Aromatic Hydrocarbons (PAHs) Present in Smoked Fish from Ghana. Advance Journal of Food Science and Technology, 3(5), 332-338.

Rasydita, H. P., Sunarto, W., \& Haryani, S. (2015). Penggunaan Asap Cair Tempurung Kelapa Dalam Pengawetan Ikan Bandeng. Indonesian Journal of Chemical Science, 4(1).

Ratna, S. H. (1990). Mikrobiologi Dasar Dalam Praktek: Teknik Dan Prosedur Dasar Laboratorium. PT Gramedia, Jakarta.
Sutanaya, N. T. A., Kencana, P. K. D., \& Arda, G. (2018). Aplikasi Asap Cair Tempurung Kelapa Mampu Meningkatkan Umur Simpan Fillet Ikan Tuna. Jurnal Beta (Biosistem Dan Teknik Pertanian), 6(2), 82-89.

Swastawati, F., Cahyono, B., \& Wijayanti, I. (2017). Perubahan Karakteristik Kualitas Ikan Tongkol (Euthynnus affinis) Dengan Metode Pengasapan Tradisional Dan Penerapan Asap Cair. INFO, 19(2), 5564. 